\title{
MEDICAL ETHNOBIOLOGY AND INDIGENOUS KNOWLEDGE SYSTEM FOUND IN DARAI ETHNIC GROUP OF CHITWAN, NEPAL
}

\section{Manisha Poudel and Nanda Bahadur Singh}

Journal of Institute of Science and Technology

Volume 21, Issue 1, August 2016

ISSN: 2469-9062 (print), 2467-9240(e)

Editors:

Prof. Dr. Kumar Sapkota

Prof. Dr. Armila Rajbhandari

Assoc. Prof. Dr. Gopi Chandra Kaphle

JIST, 21 (1), 103-111 (2016)

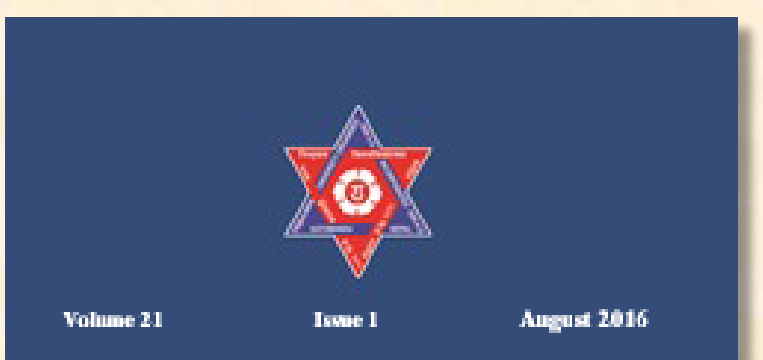

JOURNAL OF INSTITUTE OF

SCIENCE AND TECHNOLOGY

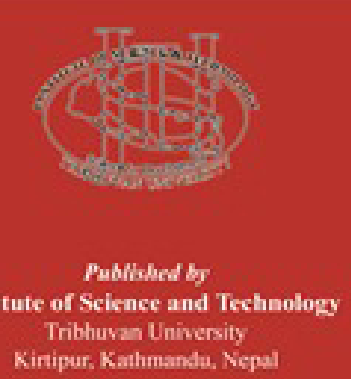

Published by:

Institute of Science and Technology

Tribhuvan University

Kirtipur, Kathmandu, Nepal 


\title{
MEDICAL ETHNOBIOLOGY AND INDIGENOUS KNOWLEDGE SYSTEM FOUND IN DARAI ETHNIC GROUP OF CHITWAN, NEPAL
}

\author{
Manisha Poudel and Nanda Bahadur Singh* \\ Central Department of Zoology, Tribhuvan University, Kirtipur, Nepal \\ *Corresponding email: nanda_nepal@yahoo.com
}

\begin{abstract}
The present study focuses on traditional usages of animals and plants species for medicinal purpose and indigenous knowledge system existent in Darai ethnic group of Mangalpur VDC, Chitwan, Nepal. A total of 28 animal species and 76 plant species were found to be used by Darai people to treat 22 and 36 different ailments, respectively. Darai people have their own indigenous knowledge for making various bamboo products and fishing equipments and local drink (moat/muna). The existence of knowledge associated with animals and plants and their medicinal utility is currently threatened mainly due to modernization, easy access to health services, lack of interest of youngsters, few local healers and fading of ethnic characters of Darai ethnic group. Thus, documentation of such knowledge has become an urgent need.
\end{abstract}

Keywords: Darai, Medicinal animals, Medicinal plants, Indigenous knowledge, Local healers

\section{INTRODUCTION}

Human beings are directly tied to nature. They use various aspects of nature including animals and plants. The survival of human directly depends on utilization of such resources. Ethnic groups around the globe are found to be close to nature and possess indigenous knowledge regarding sustainable utilization of animals and plants found in their surrounding areas (Maiti \& Maiti 2011). According to the World Health Organization (1993), about $80 \%$ of the world people rely primarily on animal and plant-based medicines. Ingredients sourced from wild plants and animals are used in traditional medicines, herbal preparations as well as in the preparation of modern medicines (Kang 2003). Thus documentation of such knowledge has become very vital.

Nepal is a small country with immense cultural and natural richness. Dramatic differences in elevation and varied ecological belts running from east to west, vertically intersected by major north to south flowing river system along with different culture support diverse form of livelihood of people (Bhattarai 1992). There are 125 indigenous nationalities in Nepal (CBS 2012). Darai is one of the marginalized ethnic tribes of Nepal. They are mainly found in Chitwan, Tanahu, Gorkha, Palpa, Nawalparasi, Dhading and Makwanpur districts of Nepal. The population of Darai Ethnic group is
16,789 and occupies $0.07 \%$ of inner Terai (CBS 2012). They are honest docile and hardworking people. Bista (1972) mentioned in his book "People of Nepal" that Darai people who live in hot wet and malarial area are reported to have grown immune to malaria. Well known for display of great health, Darai people have traditional way of life and have a close relationship with their local plants and animals. They utilize local plants, wild fruits and vegetables from ancient time for domestic purposes ranging from timber, fiber, medicine, ritual object, etc. These people traditionally acquired diversity of knowledge regarding the utilization of animal resources of the surrounding area.

In the context of Nepal, the ethnobiological study or research is more or less in the stage of void, whereas more ethnobotanical research has been accounted. The first study of a particular community was conducted by Toba (1975) on ethnobotany and village economy, followed by Coburn (1984) and Manandhar (1990). However, Singh (1995) initiated ethnobiological research in Nepal followed by other researches like Upahadaya (1991), Dhakal (1997), Pokhrel (2005) (Mahawar \& Jaroli 2008), Dangol (2010) and (Lohani 2011). Few works have been done in Darai group on the medicinal animal and plant products and documented by Dangol and Gurung (1999), Dangol (2010) etc but there is a definite scarcity of such 
knowledge when it comes to animal products and indigenous knowledge of Darai ethnic group which is the main objective of this research.

\section{MATERIALS AND METHODS}

\section{Study Area}

Mangalpur VDC lies in Chitwan district $7 \mathrm{~km}$ west from headquarter Bharatpur with Narayani river flowing on northern part. Chitwan district lies in Narayani zone and is located in southwestern corner of Central Development region. It lies in between $27^{0} 21^{\prime} 45^{\prime \prime} \& 27^{\circ} 52^{\prime} 30^{\prime \prime}$ $\mathrm{N}$ and $83^{\circ} 54^{\prime} 45^{\prime \prime} \& 84^{\circ} 48^{\prime} 15^{\prime \prime} \mathrm{E}$ at an elevation of 244-1945 m. The total area of Chitwan district is $2218 \mathrm{sq} \mathrm{km}$ which makes $1.5 \%$ of the total area of Nepal. District boundary is marked by Nawalaparasi district along with Narayani river in west, Makawanpur district in east, Parsa district and Bihar, India in south, Tanahu, Gorkha and Dhading district in north. Headquater of the district is Bharatpur which is 5th largest city of Nepal. Most part lies in Siwalik region $(86.5 \%)$ followed by Mid-Mountain (12.7\%) and Terai $(0.8 \%)$. Chitwan is one of the richest districts in terms of flora and fauna. Among total land of Chitwan $59.7 \%$ of land is occupied by forest and $34.7 \%$ land is used for agriculture and grassland. Similarly, only $2.8 \%$ of land is shrub land, $17 \%$ of total land is barren and $1.1 \%$ water bodies (Environment statistic 2008). Predominant vegetation is Sal (Shorea robusta) forest, a moist deciduous climax vegetation type of the Terai region. Chitwan district is renowned for onehorned rhinoceros, tiger, gharial crocodile, gaur, wild elephant, four horned antelope, striped hyena, pangolin, gangetic dolphin, monitor lizard, python, etc. Among birds are Bengal florican, giant hornbill, lesser florican, black stork, white stork etc.

\section{Data collection and analysis}

Ethnobiological data were gathered from March 1526, 2014 and August 10-18, 2015 using individual interviews conducted with Key informants (elder people and local healers), group discussion and jungle walk. A sample of 28 resource persons that included local healers (Dhami/Jhankri), knowledgeable elder people, community leader, medicinal plant collectors, school teacher as well as youth and local people from the study area were selected in order to fulfill the intended objectives of the present research. Plant and animal species seen during field visit were photographed. Identification of specimens was made with the help of herbarium materials, experts, taxonomic keys and literatures.

Data analysis was carried out with the help of MS excel spreadsheet by making simple calculations. The proportions were determined and pie-charts were drawn.

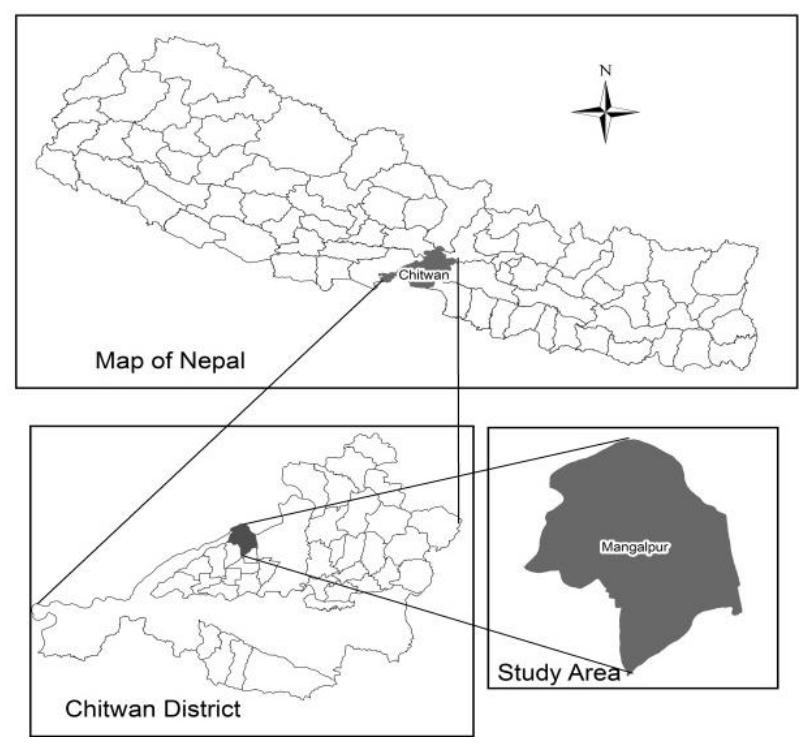

Fig. 1. Map of the study area.

\section{RESULTS}

\section{Medicinal ethnobiology}

Darai people used various animals and plant species to treat different ailments/diseases which are given in Table 1 and Table 2; respectively (see appendix). The result revealed the use of 28 animal species for treatment of 22 different ailments as shown in Table 1. Among 28 animal species 11 species belonged to class Mammalia, eight to Aves, four to Insecta, two to Reptilia and Mollusca each, and one to Pisces. Sixteen species were wild whereas remaining were domesticated. The study revealed that highest number of animals were used for the treatment of musculo-skeletal diseases (five); followed by integumentary (four); gastrointestinal and otorhino-laryngo (three each); respiratory and reproductive (two each); cardio-vascular, hematological and nervous (one each). Remaining ailments couldn't be classified in medical terms. Likewise various parts/products of animal species were used for medicinal purpose. Meat(flesh) was mostly used (25.64\%) followed by egg, fat , bone, body fluid and whole organism (7.72\% each); brain and milk (5.13\% each). Wax, shelter, carapace, blood, skin and antlers were least used (2.56\%). 
Different forms of medicine were found to be utilized. Raw being highly used $(42.1 \%)$, followed by paste $(28.94 \%)$, cooked $(21.05 \%)$ and dried, liquor and powder $(2.63 \%)$. Similarly, different routes of medication of medicinal animals were practiced. Oral absorption was mostly practiced route of medication (43.9\%) and is the only source of internal route. Whereas, external medication included apply (17.07\%), massage (14.63\%), paste (14.64\%), amulet $(4.88 \%)$ and drops $(4.88 \%)$.

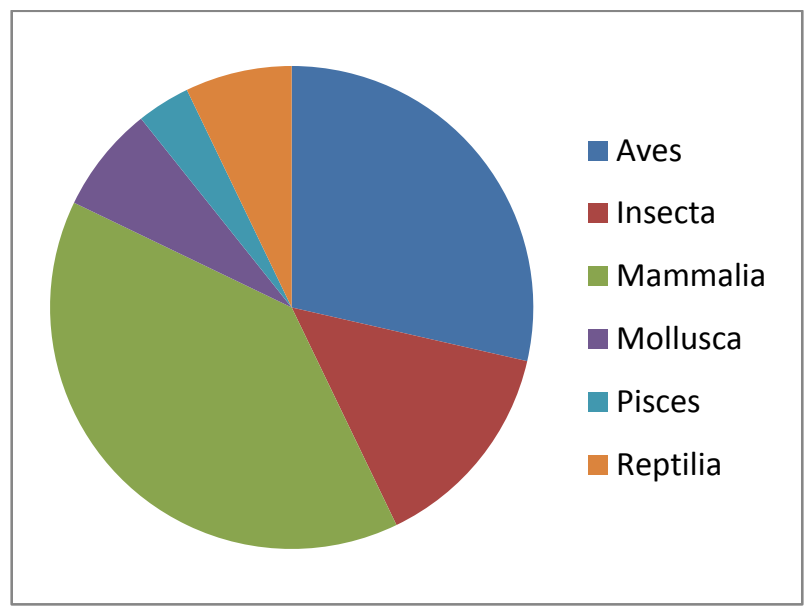

\section{Fig. 2. The number of animals belonging to different classes.}

On the other hand 76 species of plant were found to be used by Darai people for the treatment of 36 different ailments among which 23 species were trees, 13 were shrubs, 32 were herbs, 4 were climber, 2 were grass and each one of parasitic herb and creeper (Table 1). The study showed the use in treatment of different types of ailments, with gastrointestinal being commonly treated (9) followed by integumentory and musculo-skeletal, otorhino-laryngo (3each); respiratory (2); reproductive, cardio-vascular, dental, haematological and genitourinary (1 each). Remaining ailments could not be classified. Medicinal plant species were chiefly used in the form of juice $(38.46 \%)$ followed by decoction and raw $(12.82 \%$ each); powder $(10.25 \%)$; cooked and paste $(8.97 \%$ each); dried $(3.84 \%)$ and steamed $(1.28 \%)$. The commonly used parts/products included leaves (34.78\%) followed by root and fruit (15.94\% each); flower and whole plant $(7.25 \%$ each); bark, seed and rhizome (4.43\%); stem and tuber (2.89\% each). Medicinal plants were administered either externally or internally. External routes of administration included apply (25.64\%), massage
(3.84\%) and drops (2.56) whereas internal routes included oral absorption (64.10\%), chewing $(2.56 \%)$ and inhalation $(1.28 \%)$.

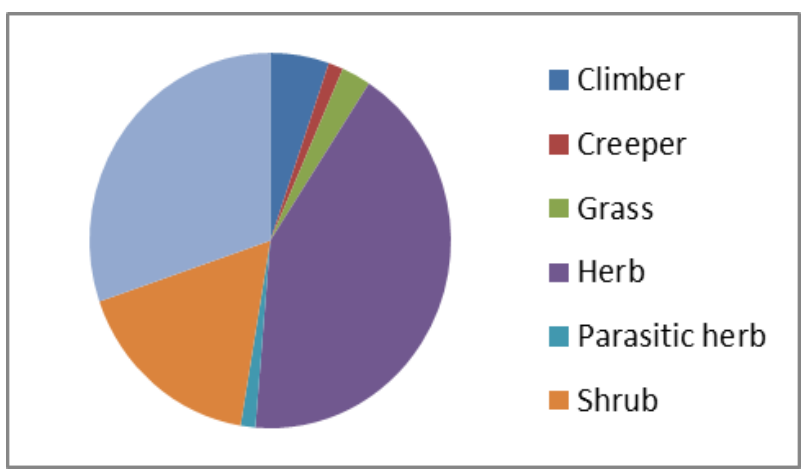

Fig. 3. Life forms of Medicinal plants.

Indigenous knowledge system prevalent in Darai community was also unveiled in the present study which is given below:

- Darai people were found to be rich in knowledge regarding the use of bamboo to make various products like baskets (Doko), craddle (Kokro), fishing basket (Dhadiya) and hat (Topi). Fishing nets and fish poisons were found to be made using plants like Aconitum spp.

- Ashes of firewood and compost manure prepared by using cattle urine and leaves of various plants were used to increase fertility of agricultural land and latter being used to treat aphids as well.

- Plants like Myrica esculenta (Kafal) Eclipta prostata (Bhringijhar) and Pogostemon benghalensis (Rudhilo) were used to extract natural dyes and colours.

- Alcohol being important parts of lives was made locally. A number of plants used for making Marcha, a starter used to prepare local beverages, were Clerodendrum viscosum (Bhanti), Vernonia cinera (Marchajhar) etc. The locally prepared alcohol is called moat/muna.

- Plant like Ipomoea aquatica (Karmisag) and animal like Philaenus spomarius (Thukekira) were used for lactation enhancement in Darai women.

Natural medicines were made to treat various ailments in domesticated animals Dried leaves of Cannabis sativa (Ganja) were fried in Ghee and 
fed to livestock to treat cold and abdominal disorder. Paste of Urtica dioca (Sisnoo) was applied to the broken legs of cattle and supported by rigid woods for fast recovery. Bixa orellana (Simrik) was given orally for speedy recovery. Tubers of Colocasia spp (Pidalu) were given to cattle to enhance lactation. Leaves of Euphorbia hirta (Pati) were spread in the cage of chicken and duck to treat body lice and mites.

\section{DISCUSSION}

Dangol and Gurung (1999), Dangol (2010) carried out studies on Darai people of Chitwan but only documented the medicinal plants used by Darai people. However, in present study medicinal animals and indigenous knowledge system prevalent in Darai community were explored. Findings of this research are supported by previous studies. For example, alcohol of meat of Canis aurens for treatment of rheumatism was supported by Dhakal (2004) and Thapa (2008). Similarly, use of honey of Apis cerana for curing cough was supported by the research works of Tamang (2003), Koirala (2004) and Thapa (2008). In present study Anadenus species was found to treat ringworm and heal fracture which was proven by Thapa (2008). Darai people used honey bee larva as source of protein and testicles of male goat for sexual power. Chalise (2010) has observed similar use as well. The antlers of Axis axis were found to be used as traditional bone strengthening in present study which was also reported by Kawtikwar et al. (2010).

Terminalia bellirica and $T$. chebula found to be used for treatment of gastritis and abdominal disorder was also supported by Ghimire (1999). Calotropis gigantean is used for treating sprain and the similar use has been observed by Ale et al. (2009), Dangol (2010) and Rai (2004). Viscum album, as in present study was also documented for its use in healing fractures by Coburn (1984). Similarly, Cuscuta reflexa and Saccharum officinarum were found to be used by Darai community in treatment of jaundice which was also mentioned in various previous researches like IUCN (2004), Thapa (2008), Malla and Chhetri (2009). Cannabis sativa, reported to be used to stop bleeding of cuts and wound in present study was also documented by Devkota and Karmacharya (2003) and Watanabe et al. (2005). Mimosa pudica reported for treatment of gastritis in present study was observed to be used in cuts and wounds by Panthi and Chaudary (2003). Urtica dioca used to heal fractures by Darai community was also reported by Rajbhandari (2001). Euphorbia hirta used for curing cuts and wounds was also observed by Manandhar (1993), Joshi and Joshi (2007). Acorus calamus was reported for treatment of sorethroat in present study. On the contrary its usage for curing tonsilitis was documented by Bhattrai et al. (2009) and Hasan et al. (2013) while Tamang (2003) reported its use in bronchitis. Likewise plants like Clerodendrum viscosum (Bhanti) and Vernonea cinera (Marchahar) were reported to be used in making local liquor which was also observed by Dangol (2008).

\section{ACKNOWLEDGEMENTS}

We are greatly indebted to Central Department of Zoology for the academic and administrative cooperation during study period. Thanks and deep appreciations to all the local people of Mangalpur VDC, and especially to Budhi Ram Darai, Dhanu Darai, Prem Darai as well as local healers Rambilas Darai and Balkrishna Jhakri for their generous contribution of time and response for enquiries.

\section{REFERENCES}

Ale, R., Raskoti, B. B. and Shrestha, K. 2009. Ethnobotanical Knowledge of Magar community in Siluwa VDC, Palpa district, Nhepal. Journal of Natural History Museum 24: 58-71.

Bhattarai, S., Chaudhary, R. P. and Taylor, R. S. L. 2009. Ethnomedicinal Plants used by people of Nawalparasi district, Central Nepal. Our Nature 7: 82-99.

Bhattrai, S. 1992. Folk herbal remedies for Gyanaecological Complaints in Central Nepal. International Journal Parmacognosy $32(1): 13$.

CBS, 2012. National Population and Housing Census. Chitwan district, Nepal.

Chalise, M. K. 2010. Suistanable Usage of Animal by the Rural people in reference to Nepal. Sustainable Use of Biological Biological Resources in Nepal, pp145-151.

Coburn, B. 1984. Some Medicinal Plants of Western Gurung. Kailash 11: 55-87.

Dangol D. R. 2010. Ethnobotany of Weeds of Chitwan district. Journal of Natural History Museum.

Dangol D. R. and Gurung, S. B. 1999. Ethnobotanical Study of Darai tribe in 
Chitwan District, Nepal. Proceeding of Third National Conference of Science and Technology.

Dangol, D. R., 2008. Taditional uses of plants of commonland habitats in Western Chitwan district. Journal of Institute of Agriculture and Animal Science 29: 71-78.

Devkota, R. and Karmacharya, 2003. Documentation of Indigenous knowledge of Medicinal Plants, Gwallek VDCs of Baitadi district, Far Western Nepal. Botanical Orientalis pp: 135-143.

Dhakal, J. 1997. Ethnobiology of the kumal in Gorkha district, Thesis. Central Department of Zoology, Tribhuvan University, Kathmandu, Nepal.

Dhakal, N. 2004. Ethnobiology of the Magars: A case study of Thimure VDC of Palpa. M.Sc. Thesis. Central Department of Zoology, T.U. Kirtipur, Kathmandu, Nepal.

Environment statistics 2008. Publisheb by Central Burea of Statistics, Kathmandu. Nepal.

Ghimire, S. K. 1999. Medicinal and Aromatic Plants in Nepal Himalaya. Status, Use, Sale and Conservation. The Wildlife 1(2): 42-54.

Hasan, H. K., Gatto, P and Jha, P. K. 2013. Traditional Uses of Wild Medicinal Plants and their Management Practices in Nepal: A study in Makwanpur district. International Journal of Medicinal and Aromatic Plants 3(1): 102-112.

IUCN. 2004. National Register of Medicinal and Aromatic Plants. (Revised and Updated). International Union for the Conservation of Nature, Nepal. Pp 202.

Joshi, A. R. and Joshi, K. 2007. Ethnomedicinal plants used against skin diseasesin some villges of Kaligandaki, Bagmati and Todi Likhu watersheds of Nepal. Ethnobotanical Leaflets 11: 235-246.

Kang S. P. (2003). Question of attitude: South Korea's Traditional Medicine Practitioners and Wildlife Conservation. TRAFFIC East Asia, Hong Kong.

Kawtikwar, P. S., Bhagwat, D. A. and Sakarka, D. A. 2010. Deer Antlers-Traditional use and future perspective. Indian Journal of Traditional Knowledge 9(2): 245-251.

Koirala, A. 2004. Ethnobiology of the Musahars: A case study of Bachhauli VDC of Chitwan District. M. Sc. Thesis. Central Department of Zoology, T. U. Kirtipur, Kathmandu, Nepal.
Lohani, U. 2011. Eroding Ethnozoological Knowledge among Magars in Central Nepal. Indian Journal of Traditional Knowledge 10:466-473.

Mahawar, M. M. and Jaroli.DP 2008. Traditional Zootherapeutic Studies in India: A Review. Journal of Ethnobilogy and Ethnomedicine 4:1-7.

Maiti, P. K. and Maiti, P. 2011. Biodiversity: perception, peril and preservation. PrenticeHall of India Pvt. Ltd. pp560.

Malla, B. and Chettri, R. B. 2009. Indigenous Knowledge on Ethnobotanical Plants of Kavrepalanchowk District. Kathmandu University Journal of Science, Engineering and Technology 5: 96-109.

Manandhar, N. P. 1990. Traditional phytotherapy of Danuwar tribes of Kamlakhonj in Sindhuli district, Nepal. Fitoterapia 61(4): 325-331.

Manandhar, N. P. 1993. Herbal remedies of Surkhet district, Nepal. Scientific World 2: 38-45.

Panthi, M. P. and Chaudhary, R. P. 2003. Ethnomedicinal Plant Resources of Argakhachi District, Western Nepal. Ethnobotany 15: 71-86.

Pokhrel, A. 2005. Ethnobiological research on the status of Tharus in Bijauri VDC of Dang. M. Sc. Thesis. Central Department of Zoology, Tribhuwan University, Kathmandu, Nepal.

Rai, S. K. 2004. Medicinal Plants used by Meche People of Jhapa District, Eastern Nepal. Our Nature 2: 27-32.

Rajbhandari, S. 2001. Medicinal Plants and Indigenous Healing Practices in Nepal. Botanica Orientalis, pp 98-100.

Singh, N. B. 1995. Study on Ethnobilogy of Endangered Tribe, the Raute, M.Sc. Thesis. Central Department of Zoology, Tribhuwan University, Kathmandu, Nepal.

Tamang, G. 2003. An ethnobiological knowledge of the Tamang people. Our Nature 1: 37-41.

Thapa, S. 2008. Medico-ethnobiological Knowledge of Magar. A case study of Salija Vdc, Parbat district, Central Nepal. Msc Thesis. Central Department of Environmental Science. Tribhuvan University, Kathamandu, Nepal.

Toba, S. 1975. Plant Names in Khaling: A study in ethnobotany and Village Economy, Kailash 3(2): 145-169. 
Upahadaya, T. 1999. Study on Ethnobiology of the Bhotes, a case study of Chhamdighat of Gulmi district, M.Sc. Thesis. Central Department of Zoology, Tribhuwan University, Kathmandu, Nepal.
Watanabe, T., Rajbhandari, K. R., Malla, K. J. and Yahara, S. 2005. A handbook of Medicinal Plants of Nepal. Ayur Seedlife Environment Institute. Japan, pp 262.

WHO (1993). Guidelines on Conservation of Medicinal Plants. Switzerland.

\section{APPENDIX}

Table 1. Animal species used to treat various ailments/diseases

\begin{tabular}{|c|c|c|c|c|c|c|c|}
\hline $\begin{array}{c}\mathbf{S} \\
\mathbf{N}\end{array}$ & Order & Family & Scientific name & Local name & Habit & $\begin{array}{c}\text { Parts/products } \\
\text { used }\end{array}$ & $\begin{array}{c}\text { Name of the } \\
\text { ailment/disease } \\
\text { treated }\end{array}$ \\
\hline 1 & Hymenoptera & Apidae & Apis cerana & Mauri & Domestic & $\begin{array}{l}\text { Honey, wax, } \\
\text { larva }\end{array}$ & $\begin{array}{l}\text { Cough, cracked } \\
\text { skin, weakness }\end{array}$ \\
\hline 2 & Hymenoptera & Ichhneumonidae & $\begin{array}{l}\text { Ichhneumonida } \\
\text { Spp }\end{array}$ & Kamalkutti & Wild & Shelter & Typhoid \\
\hline 3 & Diptera & Muscidae & Musca Spp & Mankha & Wild & Larva & Typhoid \\
\hline 4 & Hemiptera & Cercopidae & $\begin{array}{l}\text { Philaenus } \\
\text { spomarius }\end{array}$ & Thukekira & Wild & $\begin{array}{l}\text { Whole } \\
\text { organism }\end{array}$ & $\begin{array}{l}\text { Lactation } \\
\text { enhancer }\end{array}$ \\
\hline 5 & Charadiformes & Charadriidae & Vanellus indicus & Huttityau & Wild & Egg & Typhoid \\
\hline 6 & Galliformes & Phasanidae & Gallus gallus & Kukhura & Wild & $\begin{array}{l}\text { Egg, Blood, } \\
\text { Meat }\end{array}$ & \begin{tabular}{|l} 
Eczema, \\
Menstural \\
disorder, Cold
\end{tabular} \\
\hline 7 & Coraciiformes & Coraciidae & $\begin{array}{l}\text { Coracias } \\
\text { benghalensis }\end{array}$ & Theuwa & Wild & Feather & $\begin{array}{l}\text { Abdominal } \\
\text { disorder, Cold }\end{array}$ \\
\hline 8 & Columbiformes & Columbidae & Columba livia & Parewa & Domestic & Meat & $\begin{array}{l}\text { Menstural } \\
\text { disorder, Cold }\end{array}$ \\
\hline 9 & Accipitriformes & Accipitridae & Gypus Spp & Giddha & Wild & Bone & Fracture \\
\hline 10 & Galliformes & Phasanidae & Pavo cristata & Majur & Wild & Bone & Heart pain \\
\hline 11 & Passeriformes & Passeridae & Passer domesticus & Bhagera & Wild & Meat & Sexual power \\
\hline 12 & Anseriformes & Anatidae & Anas Spp & Haans & Domestic & Egg & Eczema \\
\hline 13 & Artiodactyla & Bovidae & Bos indicus & Gai & Domestic & Milk, Ghee & \begin{tabular}{|l} 
Fracture, \\
Bodyache, \\
Sprain \\
\end{tabular} \\
\hline 14 & Artiodactyla & Bovidae & Bos Taurus & Goru & Domestic & Teeth & Tonsilitis \\
\hline 15 & Artiodactyla & Bovidae & Ovis aries & Bheda & Domestic & Milk, Urine & $\begin{array}{l}\text { Fracture, } \\
\text { Earache }\end{array}$ \\
\hline 16 & Artiodactyla & Bovidae & Bubalus bubalis & Bhaisi & Domestic & Skin & Good luck \\
\hline 17 & Artiodactyla & Bovidae & Capra Spp & $\begin{array}{l}\text { Bakhra, } \\
\text { Boka }\end{array}$ & Domestic & $\begin{array}{l}\text { Meat, } \quad \text { Milk, } \\
\text { Testicles, } \\
\text { Brain }\end{array}$ & $\begin{array}{l}\text { Aphrodosiac, } \\
\text { Nervous } \\
\text { disorder, Anal } \\
\text { infection }\end{array}$ \\
\hline 18 & Artiodactyla & Cervidae & Axis axis & Mirga/Harin & Wild & Antlers & $\begin{array}{l}\text { Fracture, Bone } \\
\text { strengthening, } \\
\text { Blurred vision }\end{array}$ \\
\hline 19 & Perrisodactyla & Equidae & Equus Spp & Ghoda & Domestic & $\begin{array}{l}\text { Urine, Sweat, } \\
\text { Hoof }\end{array}$ & $\begin{array}{l}\text { Alcohol } \\
\text { addiction, } \\
\text { Typhoid } \\
\end{array}$ \\
\hline 20 & Artiodactyla & Suidae & Sus scrofa & Sungur & Domestic & Fat & Cracked skin \\
\hline
\end{tabular}




\begin{tabular}{|l|l|l|l|l|l|l|l|}
\hline 21 & Primates & Homonidae & Homo sapiens & Manche & & Milk & Eye infection \\
\hline 22 & Lagomorpha & Leporidae & Orgodactylus Spp & Kharayo & Domestic & Meat & Intestinal pain \\
\hline 23 & Carnivora & Canidae & Canis aurens & Syal & Wild & Fat, Meat & Rheumatism \\
\hline 24 & Perciformes & Channidae & Channa Spp & Bhoti & Wild & Fat, Intestine & $\begin{array}{l}\text { Cracked } \\
\text { Burns }\end{array}$ \\
\hline 25 & Testudines & Testudinade & Testudo Spp & Kachuwa & Wild & Carapace & Wounds \\
\hline 26 & Squamata & Varanidae & Varanus Spp & Sun Gohoro & Wild & Meat & Malaria \\
\hline 27 & Opisthophora & Viviparidae & Bellamya Spp & Ghogi & Wild & Meat & Malaria \\
\hline 28 & Pulmonata & Helicidae & Anadenus $S p p$ & Chiplekira & Wild & $\begin{array}{l}\text { Whole } \\
\text { organism }\end{array}$ & $\begin{array}{l}\text { Fracture, } \\
\text { Ringworm }\end{array}$ \\
\hline
\end{tabular}

Table 2. Plant species used to treat various ailments/diseases

\begin{tabular}{|c|c|c|c|c|c|c|}
\hline S.N. & Family & Scientific name & Local name & $\begin{array}{l}\text { Life } \\
\text { form }\end{array}$ & $\begin{array}{c}\text { Parts/products } \\
\text { used }\end{array}$ & Diseases treated \\
\hline 1 & Annonaceae & Annona squamosa & Sitafal,sarifa & Tree & & \\
\hline 2 & Apiaceae & Carum copticum & Jwaano & Herb & Seeds & $\begin{array}{l}\text { Menstural cramps, } \\
\text { Lactaion enhancer }\end{array}$ \\
\hline 3 & Acanthaceae & Adhatoda vasica & Asuro & Shrub & Leaves & Cough \\
\hline 4 & Acanthaceae & Rungia parviflora & Runchejhar & Herb & Whole plant & Cuts and wounds \\
\hline 5 & Araceae & $\begin{array}{l}\text { Colocasia } \\
\text { esculneta }\end{array}$ & Pindalu & Herb & Tuber & Lactaion \\
\hline 6 & Acanthaceae & Barleria cristata & Bhedekuro & Herb & Root & Anaemia \\
\hline 6 & Amaranthaceae & $\begin{array}{l}\text { Achyranthes } \\
\text { bidentata }\end{array}$ & Datiwan & Herb & Stem & Toothache \\
\hline 7 & Amaranthaceae & $\begin{array}{l}\text { Amaranthus } \\
\text { spinosus }\end{array}$ & Lunde & Herb & Seeds & Labour pain reducer \\
\hline 8 & Amaryllidaceae & Allium sativum & Lasun & Herb & Tuber & Tonsilitis \\
\hline 9 & Arecaceae & Areca catechu & Supari & Tree & Fruit & Scars \\
\hline 10 & Anacardiaceae & Mangifera indica & Aanp & Tree & Bark & Dysentry \\
\hline 10 & Apocynaceae & $\begin{array}{l}\text { Rauvofolia } \\
\text { serpentine }\end{array}$ & Sarpagandha & Shrub & Leaves & Snakebite \\
\hline 11 & Apocynaeae & Apocynaceae & Gulaichi & Tree & Flower & Fever \\
\hline 12 & Apocynaceae & $\begin{array}{l}\text { Holarrhena } \\
\text { pubescens }\end{array}$ & Dudhkhirra & Tree & Bark & Heat \\
\hline 13 & Apocynaceae & $\begin{array}{l}\text { Calotropis } \\
\text { gigoneta }\end{array}$ & Aank & Shrub & Latex & Fracture, Sprain \\
\hline 14 & Araceae & Acorus calamus & Bojho & Herb & Rhizome & $\begin{array}{l}\text { Diarrhoea, tonsillitis, } \\
\text { fever }\end{array}$ \\
\hline 15 & Asteraceae & $\begin{array}{l}\text { Mikenia } \\
\text { micarantha }\end{array}$ & Banmara & Shrub & Leaves & Cuts and wounds \\
\hline 16 & Bixaceae & Bixa orellana & Simrik & Tree & Fruit & Fracture \\
\hline 17 & Bromeliaceae & Ananas comosus & Bhuikatahar & Herb & Root & Heat \\
\hline 18 & Caryophyllaceae & Drymaria cordata & Abijaalo & Herb & Whole plant & Gastritis \\
\hline 19 & Cannabaceae & Cannabis sativa & Ganja & Herb & Leaves & Cold \\
\hline
\end{tabular}


Medical ethnobiology and indigenous knowledge system found in Darai ethnic group of Chitwan, Nepal

\begin{tabular}{|c|c|c|c|c|c|c|}
\hline 20 & Capparaceae & $\begin{array}{l}\text { Crafeiva } \\
\text { unilocularis }\end{array}$ & Siplikan & Tree & Leaves & Urinary infection \\
\hline 21 & Combretaceae & $\begin{array}{l}\text { Terminalia } \\
\text { chebula }\end{array}$ & Harro & Tree & Fruit & Gastritis \\
\hline 22 & Combretaceae & $\begin{array}{l}\text { Terminalia } \\
\text { bellirica }\end{array}$ & Barro & Tree & Fruit & Gastritis \\
\hline 23 & Compositae & Artemesia indica & Titepati & Herb & Leaves & Cuts and wounds \\
\hline 24 & Compositae & Eclipta prostate & Bhringiraj & Herb & Leaves & Cuts and wound \\
\hline 25 & Convolvulaceae & Cuscuta reflexa & Aakashbeli & $\begin{array}{l}\text { Parasitc } \\
\text { herb }\end{array}$ & Whole plant & Jaundice \\
\hline 26 & Convolvulaceae & Ipomoea aquatica & Karmi sag & Herb & Stem & Lactation \\
\hline 27 & Costaceae & Costus specious & Bethlauri & Herb & Stem & Joint pain \\
\hline 28 & Cucurbitaceae & Cucurbita maxima & Farsi & Climber & Fruit & Jaundice \\
\hline 29 & Cucurbitaceae & Cucumis stivus & Kakro & Creeper & Seeds & Heat \\
\hline 30 & Cucurbitaceae & $\begin{array}{l}\text { Trichosanthes } \\
\text { dioca }\end{array}$ & Parbal & Climber & Fruit & Heat \\
\hline 31 & Dipterocapaceae & Shorea robusta & Sal & Tree & Resin & Fracture \\
\hline 32 & Ericaceae & $\begin{array}{l}\text { Rhododendron } \\
\text { arboretum }\end{array}$ & Laaligurans & Tree & Flower & Bone prick \\
\hline 33 & Euphorbiaceae & Euphorbia roylena & Siudi & Shrub & Leaves & Dysetry \\
\hline 34 & Euphorbiaceae & Emblica officinalis & Aamala & Tree & Leaves & Snakebite \\
\hline 35 & Euphorbiaceae & Euphorbia hirta & Dudhejhar & Herb & Root & Lactation \\
\hline 36 & Euphorbiaceae & Jatropha curcas & Sajiwan & Shrub & Stem & Constipation \\
\hline 37 & Fabaceae & Mimosa pudica & Lajjawati & Herb & Root, flower & Gastritis \\
\hline 38 & Gentianaceae & Swertia nervosa & Titepati & Herb & Leaves & Cuts and wounds \\
\hline 39 & Gramineae & $\begin{array}{l}\text { Saccharum } \\
\text { officinarun }\end{array}$ & Ukhu & Grass & Stem & Jaundice \\
\hline 40 & Hypercaceae & $\begin{array}{l}\text { Hyperiucum } \\
\text { cordifolium }\end{array}$ & Areli,Areto & Shrub & Bark & Rheumatism \\
\hline 41 & Juglandaceae & Juglans regia & Okhar & Tree & Fruit & Typhoid \\
\hline 42 & Lamiaceae & $\begin{array}{l}\text { Pogosteomon } \\
\text { benghalensis }\end{array}$ & Rudhilo & Herb & Leaves & Typhoid, sinutisis \\
\hline 43 & Lamiaceae & Ocimum santum & Tulsi & Herb & Leaves & Tonsilitis \\
\hline 44 & Lamiaceae & Ocimum basilicum & Babari & Herb & Leaves & Fever \\
\hline 45 & Lamiaceae & Leucas Spp & Gumpati & Herb & Leaves & Abdominal disorder \\
\hline 46 & Loranthaceae & Viscum album & Hadchur & Shrub & Whole plant & Fracture \\
\hline 47 & Lygodiaceae & $\begin{array}{l}\text { Lygodium } \\
\text { japonica }\end{array}$ & Janai Lahara & Climber & Leaves & Ringworm \\
\hline 48 & Malvaceae & Bombax ceiba & Simal & Tree & Root, flower & Measles, Dysentry \\
\hline 49 & Meciaceae & Azadirachta indica & Neem & Tree & Leaves & Wounds, worms \\
\hline 50 & Menispermaceae & Tinospora sinensis & Gurjo & Climber & Rhizome & Earache \\
\hline 51 & Menispermaceae & $\begin{array}{l}\text { Cissampelos } \\
\text { pareira }\end{array}$ & Batulpate & Herb & Roots & Cough, Worms \\
\hline 52 & Moraceae & $\begin{array}{l}\text { Artrocarpus } \\
\text { lakoocha }\end{array}$ & Badahar & Tree & Bark & Gastritis \\
\hline 53 & Moraceae & Ficus benghalensis & Bar & Tree & Leaves & Gastritis \\
\hline
\end{tabular}




\begin{tabular}{|c|c|c|c|c|c|c|}
\hline 54 & Musaceae & Musa paradisiacal & Keraa & Herb & Flower & Chest pain \\
\hline 55 & Myricaceae & Myrica esculenta & Kaaphal & Tree & Fruit & Abdominal pain \\
\hline 56 & Myrtaceae & Psidium guajava & Ambaa & Tree & Leaves & Diarrhoea \\
\hline 57 & Myrtaceae & $\begin{array}{l}\text { Syzygium } \\
\text { aromaticum }\end{array}$ & Lwang & Tree & Fruit & Tonsilitis \\
\hline 58 & Oleaceae & $\begin{array}{l}\text { Nyctanthes } \\
\text { arbortristis }\end{array}$ & Parijat & Tree & Leaves & Heat \\
\hline 59 & Onocleaceae & $\begin{array}{l}\text { Matteuccia } \\
\text { struthiopteris }\end{array}$ & Neuro & Herb & leaves & $\begin{array}{l}\text { Diarrhoea, Blood in } \\
\text { stool }\end{array}$ \\
\hline 60 & Oxalidaceae & Oxalis corniculata & Chariamilo & Herb & Leaves & Earache \\
\hline 61 & Poaceae & Cynodon dactylon & Dubo & Grass & Leaves & Hair stuck in neck \\
\hline 62 & Poaceae & $\begin{array}{l}\text { Thyranolaena } \\
\text { maxima }\end{array}$ & Amriso & Shrub & Seeds & $\begin{array}{l}\text { Urinary infection, } \\
\text { Placenta retention }\end{array}$ \\
\hline 63 & Polygonaceae & $\begin{array}{l}\text { Fagopyrum } \\
\text { esculentum }\end{array}$ & Fapar & Herb & Seed & Typhoi \\
\hline 64 & Rhamnaceae & $\begin{array}{l}\text { Ziziphus } \\
\text { mauritiana }\end{array}$ & Bayer & Shrub & Fruit & Cough \\
\hline 65 & Rutaceae & Citrus medica & Bimiro & Tree & Root & Dysentry \\
\hline 66 & Rutaceae & Aegle marmelos & Bel & Tree & Leaves & Diabetes \\
\hline 68 & Solanaceae & $\begin{array}{l}\text { Withania } \\
\text { somnifera }\end{array}$ & Ashwaganda & Shrub & Leaves & Abdominal disorder \\
\hline 69 & Solanaceae & $\begin{array}{l}\text { Solanum } \\
\text { capsicoides }\end{array}$ & Kantakaari & Shrub & Root & Asthma, Chest pain \\
\hline 70 & Solanaceae & $\begin{array}{l}\text { Solanum } \\
\text { melongene }\end{array}$ & Bhanta & Shrub & Root & Placenta retention \\
\hline 71 & Umbelliferae & Centella asiatica & Ghortaapre & Herb & Leaves & Jaundice \\
\hline 73 & Umbelliferae & Anethum sowa & Swoup & Herb & Seed & Lactation enhancer \\
\hline 74 & Urticaceae & Urtica dioica & Sisno & Herb & Leaves & Blood pressure \\
\hline 75 & Xanthorrhoeaceae & Aloe vera & Ghiukumari & Herb & Leaves & Burns \\
\hline 76 & Zingiberaceae & Amomum zingiber & Aduwa & Herb & Rhizome & Cough \\
\hline
\end{tabular}

